\title{
Analysis of Climate Change Impact on Water Supply in Northern Istria (Croatia)
}

\author{
Barbara KARLEUŠA, Josip RUBINIĆ, Maja RADIŠIĆ, Nino KRVAVICA
}

\begin{abstract}
This paper analyses impacts of climate change and anthropogenic pressure on groundwater resources in the Mirna river catchment used for water supply in Northern Istria (Croatia) up to 2050. Using Regional Climate Models simulations and hydrologic model, the future average annual and the characteristic (in critical period) water resource availabilities were calculated. Current and five future water demand scenarios were analysed. Water Exploitation Index (WEI) and modified Characteristic Water Exploitation Index (CWEI) were calculated. In 2050, the analysed springs will be subject to climate change consequences, with more extreme changes and intense variations. The WEI for average conditions indicates little risk of unmet future water demand. Considering seasonal variability, the future $\mathrm{CWEls}$ indicates strong risk for most future water demand scenarios and overexploitation for water demand increases over $20 \%$. The 2012 drought, more extreme than any considered future scenario, was also examined.
\end{abstract}

Keywords: climate change; drinking water supply; water resources availability

\section{INTRODUCTION}

The Mediterranean basin, including the Adriatic Sea region, is a region that is very sensitive to climate change and anthropogenic impacts [1]. According to Xoplaki et al. [2], since the 1970s, the mean annual temperatures in the Mediterranean region have increased by $0.1^{\circ} \mathrm{C}$ per decade, and precipitation has decreased by $25 \mathrm{~mm}$ per decade. Temperatures are expected to increase by $1.5-2.5^{\circ} \mathrm{C}$, and precipitation is expected to decrease by $5 \%$ to $20 \%$ up to 2050 [3], which could significantly decrease (30-50\%) freshwater resources throughout the Mediterranean basin. In the Adriatic region, the decrease of $15 \%$ of freshwater is expected in northern Italy and the Balkans [3]. Climate changes cause more frequent drought and flood occurrence. On the other hand, an increase in water demand is expected due to increasing urbanisation, agricultural production and tourism activities, increasing the withdrawal of and pressures on regional water resources [4]. Changes in land use potentially affect the available water resources too (e.g. increased intercepted precipitation in case of enlarging the forest area [5]).

Water resource and supply vulnerability and risk assessments, water scarcity estimates and drought analyses due to climate change impacts are necessary for avoiding future water crises and preparing adaptation measures to mitigate the consequences of such crises [6,7].

Numerous studies have investigated the impact of climate change on water resources worldwide (e.g. [8]); many have also analysed the impacts of human activities on water resources (e.g. [9]). Recently, more research has been conducted to simulate the impacts of climate change on water resources in future. This can be done by using various methodologies [10]: coupling Global Circulation Models (GCMs) with hydrologic models through downscaling techniques, coupling high-resolution Regional Climate Models (RCMs) with hydrologic models and using hypothetical scenarios as inputs to hydrologic models. Coupling high-resolution RCMs with hydrologic models has frequently been used to model the climate change impacts on hydrological regimes and water resources in the mid- to long-term future in Europe [11, $12]$.
Regardless of the methodology used to simulate climate change, the impact of climate change on the water resources in the Mediterranean has been confirmed in different studies [13-15]. Based on scenarios of varying future temperature and precipitation to analyse the changes in groundwater recharge and in agricultural water demand for the West Bank of the Mediterranean basin, Mizyed 15] concluded that the groundwater recharge could decrease by up to $50 \%$.

Water supply system and sources vulnerability due to climate change are analysed by researchers in the Monterrey Metropolitan Area of northern Mexico [7] and on Mexico City [16]. However, only a small number of papers have investigated mitigation measures and adaptive strategies for drinking water supply $[4,17]$.

Impact of climate change on water resources used for drinking water supply in the Adriatic region has been investigated within the DRINKADRIA project $[18,19]$.

This paper presents the investigation of the climate change impacts and the anthropogenic pressure on groundwater resources in the river Mirna catchment that are used for drinking water supply in Northern Istria (Croatia, Northern part of the Adriatic sea region) to give the basis for preparation of adaptation and mitigation strategies up to year 2050. Analysing the impacts of climate change on water resource availability consists of using RCMs to simulate the change in temperature and precipitation up to 2050 . Then, based on the results from climate modelling, a hydrological model is applied to calculate the future average annual water resource availability and characteristic renewable water resources availability (critical period), which are compared to past availability to estimate the changes.

Water demand analysis was conducted for the present demand and for five future water demand scenarios. To estimate the water resource vulnerability in Northern Istria, the Water Exploitation Index (WEI) was calculated [20]. However, to encompass the strong seasonal variability of the water demand and water resource availability, a modified Characteristic Water Exploitation Index (CWEI) was also used.

The 2012 drought, which was more extreme than any considered future scenario, was also examined. 


\section{STUDY AREA}

The river Mirna catchment is the largest drainage basin and watercourse in the Istria peninsula and covers approximately $700 \mathrm{~km}^{2}$ (Fig. 1).

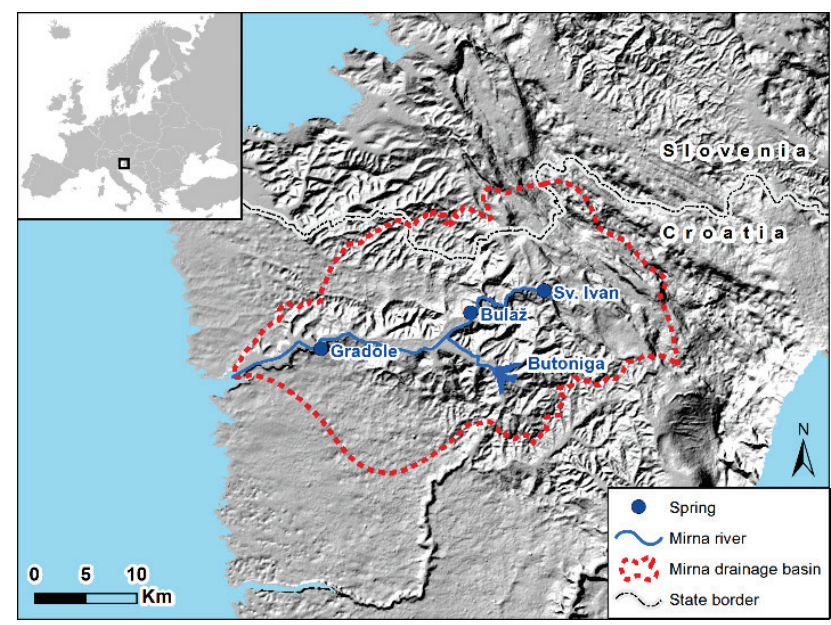

Figure 1 Mirna River catchment and location of springs Sv. Ivan, Bulaž and Gradole and Butoniga reservoir

The area of Istrian Peninsula is spreading over 3476 $\mathrm{km}^{2}$, of which $2820 \mathrm{~km}^{2}$ administratively belongs to Istria County. The Mirna catchment area belongs to the periphery of the Adriatic Carbonate platform. This geological structure includes carbonate and clastic deposits with stratigraphic ranges from the Upper Jurassic to the Eocene. The parts of the Istrian Peninsula where the surface watercourses are developed are mostly composed of flysch. The northern and northeastern parts of Istria are characterized by significant structural disturbances of the high carbonate massif of Mt Učka and Mt Ćićarija. The central and southeastern parts of Istria belong to the Pazin flysch basin, while the northwestern edge of this area belongs to the Trieste flysch basin. The Buje carbonate anticline rises between these basins, while the western and southwestern parts belong to the western Istrian carbonate anticline. The Mirna River formed its course between the abovementioned structures and partly through a valley area composed of an alluvial deposit reaching deep below sea level, thus retarding groundwater flow.

Groundwater emerges from the aquifer, in the form of several significant karst springs in the Mirna catchment at a contact point between the karst hinterland and the alluvial deposits. These springs are Sv. Ivan in the upper Mirna course $\left(45^{\circ} 24^{\prime} 03.2^{\prime \prime} \mathrm{N} 13^{\circ} 58^{\prime} 39.5^{\prime \prime} \mathrm{E}\right)$, Bulaž in its middle course $\left(45^{\circ} 22^{\prime} 46.5^{\prime \prime} \mathrm{N} 13^{\circ} 53^{\prime} 17.4^{\prime \prime} \mathrm{E}\right)$, and Gradole in its lower course $\left(45^{\circ} 20^{\prime} 37.9^{\prime \prime} \mathrm{N} 13^{\circ} 42^{\prime} 10.9^{\prime \prime}\right.$ E) (Fig. 1).

The already observed manifestations of climate change are predicted to intensify in this area, where the majority of run-off goes underground, and karst springs are the main water supply resource [21].

Approximately $50 \%$ of the Mirna water balance (11.3 $\mathrm{m}^{3} \mathrm{~s}^{-1}$ estimated at the river mouth) is accounted for by the Sv. Ivan $\left(0.82 \mathrm{~m}^{3} \mathrm{~s}^{-1}\right)$, Gradole $\left(2.1 \mathrm{~m}^{3} \mathrm{~s}^{-1}\right)$ and Bulaž $(1.4$ $\left.\mathrm{m}^{3} \mathrm{~s}^{-1}\right)$ springs, as well as by several other minor springs (e.g., Tombazin) that are not under the official hydrological monitoring programme [22].

During prolonged dry periods, water flowing from the karst springs is almost the only inflow to the Mirna River.
The area of the Mirna catchment is most significant in terms of the available groundwater and surface water resources included in the water supply system of Istarski vodovod (Water Utility of Istria), the largest of the three water supply companies in Istria County.

Using spring water for water supply adds pressure to the water resources and the ecosystem of the Mirna River, particularly during the extremely dry years that are becoming increasingly more frequent. The coastal area that is supplied by these springs mostly host tourist activity, leading to increased water demand in the summer months, when the spring yield is the lowest.

Severe dry events during the last several decades (e.g., 1986-89, 2002-03, and 2011-12) have shown that the exploitable water resources available in Istria within the constructed water supply systems are at the limit of meeting the current needs. A potential solution is to better optimise the provision of seasonal water reserves from the

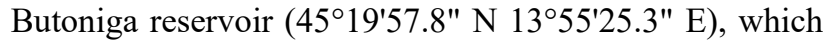
also lies in the Mirna catchment (Fig. 1). This reservoir has a volume of approximately 20 million $\mathrm{m}^{3}, 8$ million $\mathrm{m}^{3}$ of water is used for water supply annually.

Due to the proximity of the individual spring catchments and the close occurrences of both wet and dry periods, the water balance characteristics of these three most significant spring water intakes in this area (i.e., Sv. Ivan, Gradole and Bulaž) are presented and analysed in the aggregate in this paper (Fig. 2).

A)
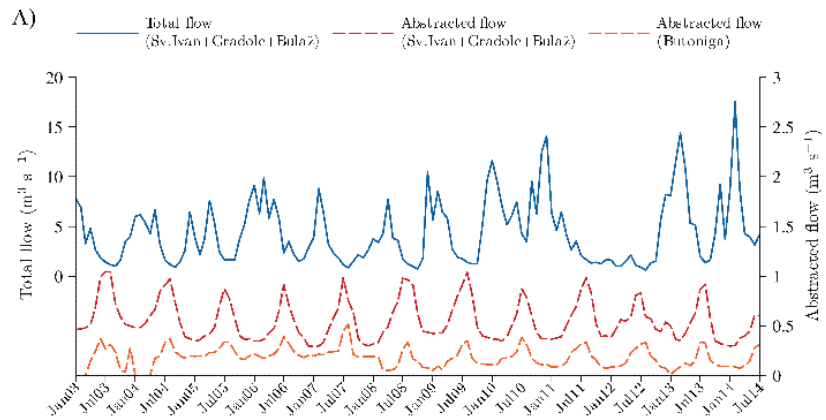

B)

Date

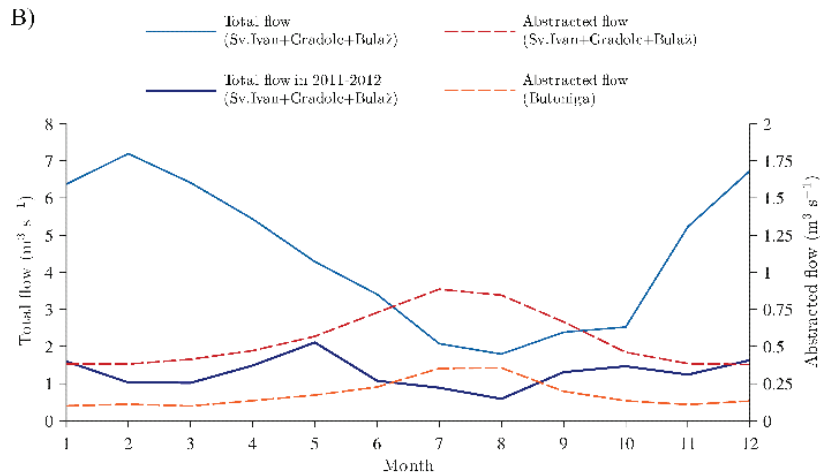

Figure 2 Distribution of: a) the average monthly discharge and abstracted flow of Sv. Ivan, Gradole and Bulaž springs and Butoniga reservoir (2003-2014); b) Inter-annual distribution of the total discharge and water pumping of Sv. Ivan, Gradole and Bulaž springs and Butoniga reservoir (2003-2014) with the interannual distribution of the total discharge in the extremely dry 2011-2012

Data used for this research (overflow and abstracted water quantities at selected springs that were used for estimation of springs yield) are provided by Croatian Meteorological and Hydrological Service based on their monitoring system. 
During dry summer periods, approximately 3.57 million tourists (as registered during 2015) are visiting dramatically increasing the permanent population of approximately 210000 . The increased water demand during summer is affected not only by tourist activities but also by the demand for water to irrigate private lawns and community parks.

These springs are highly sensitive to climate change and droughts that can significantly reduce the available water balance of these springs. The year 2012 was particularly critical as the area experienced a low water event with a return period of between 100 and 200 years [23].

\section{METHODOLOGY \\ 3.1 Methodology for Analysing the Impact of Climate Change on Water Resources}

The methodology used to assess the impact of climate change on water resources in the analysed area of Northern Istria was described in detail by Rubinić and Katalinić [24].

The proposed model uses a runoff estimation based on a spatial distribution of the annual rainfall and air temperature in the GIS environment. The localized measurements at specific points are distributed over the entire basin area using point-weighted averages. The Langbein [25] and Turc [26] empirical expressions were used for this purpose. The choice of an appropriate runoff distribution was based on a comparison of data from basins with available observations of climatological indicators and measured discharges. The Turc method was used for regional hydrological water balance assessment for karst basins [27], but in this case study the Langbein method was chosen as the most appropriate for the analysed karstic springs located in the Mirna river catchment [28]. This concurs with an established practice in regional hydrological approach of using empirical models that are calibrated based on the results of hydrological observations during the period of 1961-2013 [27-29].

The approach used here is based on the analysis of the historical climatological and hydrological data (19612013) to generate the data for the period of 2014-2050. Using these models along with the spatial assessment of the annual rainfall and the average annual air temperatures in the analysed basin and determining the basin surface area using hydro-geological methods, it is possible to define the spatial distribution of the actual annual rainfall, i.e., the rainfall that infiltrated into the karst aquifer basin.

In the process of modelling, both point and spatially distributed data for the annual rainfall and the average annual air temperatures were used. Pazin, the main climatological station located in the central part of the Istrian Peninsula, was selected as the reference station, and the historically recorded data from the period of 1961-2013 were analysed. The spatial distributions of the average annual air temperature and precipitation for the reference time period of 1961-1990 were also used. Estimations of the average annual air temperature and precipitation for the time period of 2014-2050 were based on the available data from the main climatological station.

Then, the impacts of climate change on hydrological characteristics, the average annual discharge and the lowest average monthly discharges, were estimated. The modelling of the annual runoff is based on the acceptable correlation $(r=0.85)$ between average annual and lowest average monthly discharges of the analysed springs in the Mirna river basin. This correlation was determined from the regression analysis of available historical data and discharge measurements in the period of 1961-2013. Additionally, the generated data series of the lowest average monthly discharges were determined, which usually represent a critical factor in securing the water availability during an increased seasonal water supply demands in the analysed area that is characterized by strong tourism activities.

Due to the high uncertainty in estimation of future climate characteristics three climate models were used. The discharge data were generated by regional climate models REGCM3 [30], ALADIN [31] and PROMES [32]. The selected RCMs were forced by the observed and predicted concentrations of the greenhouse gases (GHGs) based on several scenarios, including the IPCC's (Intergovernmental Panel on Climate Change) A1B scenario of the GHGs emissions for the period after 2001. The initial and boundary data for each RCM were provided from different global climate models (GCMs): the ECHAM5 GCM data were used to force REGCM3, ALADIN was forced by the Arpege GCM and PROMES was forced by the HadCM3Q GCM [33].

A homogeneity assessment of the results based on the historical time series and on the two chosen models was performed using the Wilcoxon test [34]. The trend analysis was conducted, both in terms of a common approach based on linear correlation and also by using the Theil-Sen's estimator $[35,36]$. Testing the significance of trends was carried out using nonparametric Man-Kendall's test [37, 38].

\subsection{Methodology for Estimation of the Water Exploitation Index}

The Water Exploitation Index (WEI) was applied to estimate the water resource vulnerability. WEI is a ratio of the average annual total water demand to the average annual available water resources and is often used to assess water stress at a national level based on total water use and the average annual water availability [20]. However, such an analysis cannot fully reflect the stress at a local level, e.g., river basins or systems of karst springs. Furthermore, because the original WEI is based on mean annual data, it does not account for seasonal variations in water demand or availability. Seasonal variations are especially important in coastal Mediterranean regions, such as Northern Istria, where the domestic, tourist and agricultural water demand peak coincides with minimum water resources availability in summer. Considering these specific concerns, the original formula was modified here for local analysis and critical periods.

Water Exploitation Index (WEI) was computed to assess the average annual conditions as a ratio of the Average Water Demand (WD) to the Average Water Resources (WR):

$W E I=W D / W R$ 
The Characteristic Water Exploitation Index (CWEI) was used to assess the vulnerability of water resources considering the strong seasonal variability in Northern Istria. In particular, the characteristic water demand focused on August, which is a typical summer month characterized by very high temperatures and low precipitation along with increased tourism and agricultural water needs. CWEI is defined as the ratio of the Characteristic Water Demand $(C W D)$ to the Characteristic Water Resources $(C W \mathrm{R})$ :

\section{$C W E I=C W D / C W R$}

Water demands and resources in Northern Istria were assessed using a simplified approach based on the statistical analysis of the observed hydrological data (i.e., abstracted and total flow) from Sv. Ivan, Gradole and Bulaž springs as well as the Butoniga reservoir. Average Water Demand ( $W D)$ was computed as the long-term mean annual abstracted flow, whereas Characteristic Water Demand $(C W D)$ was computed as the long-term mean August abstracted flow, from Sv. Ivan, Gradole and Bulaž springs, and the Butoniga reservoir. Water resources were based mainly on the measured total flow from the Sv. Ivan, Gradole and Bulaž springs. The main issue was accounting for the water reserves in the Butoniga reservoir. Clearly, omitting these quantities from the resource analysis would overestimate the WEI and CWEI. However, the Butoniga reservoir does not have any external inflow other than direct precipitation. Therefore, two water resources scenarios were evaluated: scenario 1 was used to estimate water resources by considering total flows only at the Sv. Ivan, Gradole and Bulaž springs ( $W R_{1}$ and $\left.C W R_{1}\right)$, and scenario 2 considered total flows at the springs and the abstracted flow from the Butoniga reservoir $\left(W R_{2}\right.$ and $\left.C W R_{2}\right)$. The average water resources $\left(W R_{1}\right.$ and $\left.W R_{2}\right)$ were computed as the mean annual total flow, whereas the characteristic water resources $\left(C W R_{1}\right.$ and $\left.C W R_{2}\right)$ were computed as the minimum mean monthly total flow.

In addition to the long-term statistical data, the extremely dry year of 2012 was examined in more detail to determine how these results match long-term projections. Both the average Water Exploitation Index WEI ${ }^{2012}$ (2012 calendar year and hydrological year) and the Characteristic Water Exploitation Index $C W E I^{2012}$ (the critical month of August 2012) were considered.

For the original method [39], WEI $<0.1$ indicates no stress, while $W E I>0.4$ indicates severe stress. Although this classification is reasonable for average conditions at a national level, when considering characteristic water conditions at a local level, these thresholds are too rigorous. Both Alcamo et al. [40] and Smakhtin et al. [41] recognized that these threshold values are too low, and they defined slightly higher boundaries. This work used a similar classification that was proposed in a CC-WaterS project that considered climate change and its impacts on water supply in South-eastern Europe: WEI $<0.50$ indicates low risk, $0.5 \leq W E I<0.7$ indicates possible difficulties, $0.7 \leq W E I<1.0$ indicates strong risk, and $W E I$ $\geq 1.0$ is considered to be unsustainable [33].

\section{RESULTS AND DISCUSSION}

\subsection{Impact of Climate Change on Water Resources}

Results of the generated minimum average monthly discharge according to the three climatological models and their future estimates based on the historically available aggregate average monthly discharge from the springs Sv. Ivan, Gradole and Bulaž for the period of 1961-1990 are presented in Fig. 3.
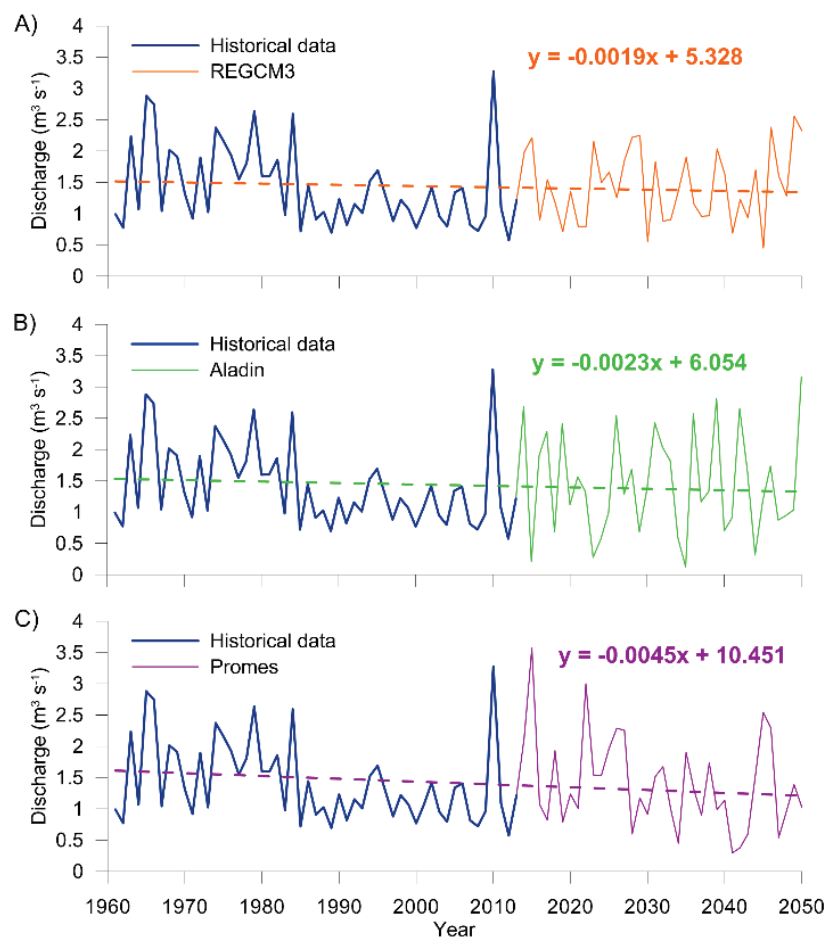

Figure 3 Historical time series and projected time series of the total lowest average monthly discharge of Sv. Ivan, Gradole and Bulaž springs generated using different climate models for 1961-2050 with accompanying trends: A) REGCM3, B) ALADIN, and C) PROMES models

The trends show that on a longer timescale and 2050, a decreasing trend in the selected characteristic discharge is expected to continue. More importantly, considering the water availability of the analysed springs, the trends suggest a possibility for a more frequent occurrence of the extremely low values of the lowest average monthly discharges.

However, each of the applied models gives different scenarios for the future changes and different slopes of these trends. According to the implemented Mann-Kendal test, the trend for the entire analysed series of historical data and projected values for the future (up to 2050), at the significance level of $5 \%$, there is no apparent decrease of mean annual flow rates according to results obtained by the use of REGCM3 ( $P$-value 0.216$)$ and the ALADIN model $(P$-value 0.101$)$, while in the results using PROMES, such a trend (P-value 0.031) was established. This statistically significant trend (Fig. 3) for the discharges generated by the PROMES model amounts to $0.45 \mathrm{~m}^{3} \mathrm{~s}^{-1}$ over 100 years.

In other words, the PROMES model predicts a decrease of the lowest average monthly discharges for almost a third of the measured historical data.

The homogeneity of the historical and generated time series of inflows based on REGCM3, ALADIN and PROMES models results was analysed using the Wilcoxon 
test. According to the results of this test, analysed series of historical (for the 30-year reference series 1961-1990, as well as in the case of a more complete historical series from 1961 to 2013) and generated future data (30-year series 2021-2050, or in the case of a more complete sequence analysis of 2014-2050), are mutually homogeneous in all analysed cases.

This analysis shows also that the lowest nonhomogeneity was recorded for the REGCM3 model. This model is usually used in the wider region of the analysed Croatian localities and it has been used for the longest for climate predictions caused by climate change [42]. The results of these models were used as input values in hydrological models, with which hydrological changes in the water regime of water resources were generated in other areas of Croatia [27, 33].

Tab. 1 presents the relationship between the projected lowest average monthly discharge for the future periods and the historical inflows, which were determined using measured historical data, as well as the generated data based on measured annual rainfall and temperatures.

The comparison also analysed the relationship between two characteristic 30-year periods, i.e., the reference historical period of 1961- 1990 and the projected period of 2021-2050, as well as the entire available historical period of 1960-2013 and the entire projected period of 2014-2050.

The average values of the minimum average monthly discharge from the end of the generated period (20212050) are significantly lower than the corresponding values from the 30-year historical period (1961-1990) in the inflow series for the entire climate models used. For the discharge generated using the REGCM3 model, this difference is the smallest with a discharge decrease of $8.6 \%$, while for the discharge generated using the PROMES model, this difference is the largest with a decrease of $15.6 \%$. However, more prominent differences are expected regarding an increase of the discharge variability, as well as a more frequent occurrence of the lower average monthly discharges, generated by the ALADIN model (66.9\%). Similar results are found when the data generated by the selected climate models for the period 1914-2050 are compared to the historical data from 1961-2013. This is also true when the generated data in a characteristic 30-year period (2021-2050) is compared to the historical data from 1961-1990. Possible differences in the occurrence of the minimal values generated by all three climate models are even more pronounced and amount up to $80 \%$.

Table 1 Statistical analysis of the measured and generated aggregate lowest average monthly discharge from Sv. Ivan, Gradole and Bulaž springs, expressed as a percentage relative to the historical series, 1961-1990 and 1961-2013, (Note: Avg - average, SD - standard deviation, Cv - coefficient of variation, Max - maximum, and

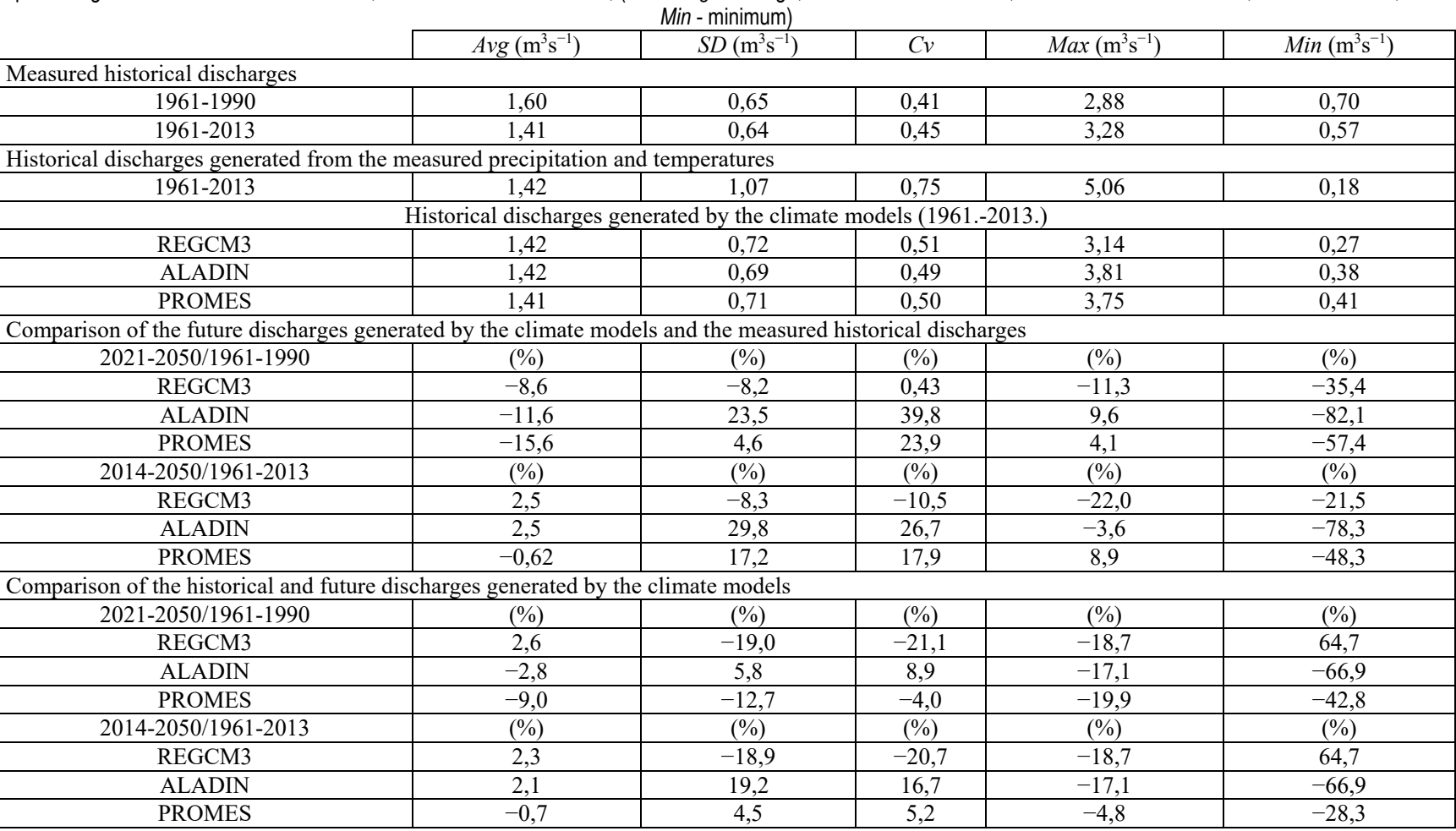

However, a decrease of the average discharges is found only in the data series generated by the ALADIN model $(-9 \%)$, and only for the period closer to the middle of the $21^{\text {st }}$ century.

When the generated data for the future period of 20142050 are compared to the historical data from the period of 1961-2013, the analysed maximum values of the lowest average monthly discharge show different results: according to the PROMES and ALADIN models, they could even increase by $4.1 \%$ and $9.6 \%$, respectively, while according to the REGCM3 model, they could decrease by $11.3 \%$. In addition, the variability of the analysed lowest average monthly discharge is expected to increase.

If the generated and historical data of the lowest average monthly discharge after 2014 and until the end of 2013 are compared, smaller discharge differences and variabilities are obtained. The reason for this could be the change of dynamics, i.e., the gradually increasing impacts of climate change on discharge, or because climate change has already somewhat manifested in the historical and 
generated periods that were not covered by the selected 30year reference period (1991-2020).

\subsection{Water Exploitation Index}

The results of the hydrological analyses were used to assess the potential impacts of climate change, i.e., a general decrease in discharge based on the exploitation of water for water supply needs. For this purpose, the Water Exploitation Index was calculated for Northern Istria, considering average (annual) and characteristic (monthly) hydrological conditions. In addition to the current water resources (1991-2014), past values (1961-1990) and several future predictions (2021-2050) from the three climate models (i.e., REGCM3, ALADIN and PROMES) were considered. Similarly, in addition to the current water demand (1991-2014), several future (2021-2050) scenarios were considered with varying increases in the current water demand of up to $25 \%$ with increments of $5 \%$. These increases were estimated from the long-term population projections and planned accommodation capacities for tourists. According to the Croatian census [43], the total population in the Istria County increased from 206344 in 2001 to 208055 in 2011 , which amounts to $0.08 \%$ per year. This increase is largely attributed to the immigration from other parts of the country and is not expected to rise in the future $[43,44]$. Considering a linear continuation of this trend, the population by 2050 is estimated to reach 215000 (a $3.2 \%$ increase). The accommodation capacities, on the other hand, are expected to increase from 210000 , which were available in 2001 , to 285000 by 2050 [42], which amounts to a $35.7 \%$ increase. Therefore, if these ambitious plans are realised, the population and accommodation capacities will together reach 500000 by the year 2050, and the total water demand is estimated to increase up to $25 \%$. It should be stressed that a decrease of the water demand could also be feasible if a different approach to water demand management issued (i.e. green infrastructure, grey water reuse, artificial aquifer recharge, better management of the water supply losses, an increased water supply efficiency in general, etc.) but this is not analysed in this paper.

Tab. 2 shows the estimated WEI and CWEI for Northern Istria.

Table $2 W E I$ and $C W E I$ for Northern Istria

\begin{tabular}{|c|c|c|c|c|c|c|c|}
\hline \multirow{4}{*}{\multicolumn{3}{|c|}{$\begin{array}{l}\text { Average annual } \\
\text { conditions }\end{array}$}} & \multicolumn{5}{|c|}{$W R_{1}\left(W R_{2}\right)\left(\mathrm{m}^{3} \mathrm{~s}^{-1}\right)$} \\
\hline & & & \multirow{2}{*}{$\begin{array}{c}\text { Past } \\
1961-1990\end{array}$} & \multirow{3}{*}{$\begin{array}{c}\text { Present } \\
1991-2014 \\
4.299(4.396)\end{array}$} & \multicolumn{3}{|c|}{ Future 2021-2050 } \\
\hline & & & & & REGCM3 & ALADIN & PROMES \\
\hline & & & $4.8(4.897)$ & & $4.64(4.737)$ & $4.5(4.597)$ & $4.83(4.927)$ \\
\hline \multicolumn{3}{|c|}{$W D\left(\mathrm{~m}^{3} \mathrm{~s}^{-1}\right)$} & \multicolumn{5}{|c|}{$W E I_{1}=W D / W R_{1}\left(W E I_{2}=W D / W R_{2}\right)$} \\
\hline \multicolumn{2}{|c|}{$1991-2014$} & 0.71 & $0.15(0.15)$ & $0.16(0.16)$ & $0.15(0.15)$ & $0.16(0.16)$ & $0.14(0.14)$ \\
\hline Future & $5 \%$ & 0.73 & $0.15(0.15)$ & $0.17(0.17)$ & $0.16(0.15)$ & $0.16(0.16)$ & $0.15(0.15)$ \\
\hline Future & $10 \%$ & 0.77 & $0.16(0.16)$ & $0.18(0.17)$ & $0.17(0.16)$ & $0.17(0.17)$ & $0.16(0.16)$ \\
\hline Future & $15 \%$ & 0.80 & $0.17(0.16)$ & $0.19(0.18)$ & $0.17(0.17)$ & $0.18(0.17)$ & $0.17(0.16)$ \\
\hline Future & $20 \%$ & 0.84 & $0.17(0.17)$ & $0.19(0.19)$ & $0.18(0.18)$ & $0.19(0.18)$ & $0.17(0.17)$ \\
\hline Future & $25 \%$ & 0.87 & $0.18(0.18)$ & $0.20(0.20)$ & $0.19(0.18)$ & $0.19(0.19)$ & $0.18(0.18)$ \\
\hline \multirow{4}{*}{\multicolumn{3}{|c|}{$\begin{array}{l}\text { Characteristic monthly } \\
\text { conditions }\end{array}$}} & \multicolumn{5}{|c|}{$C W R_{1}\left(C W R_{2}\right)\left(\mathrm{m}^{3} \mathrm{~s}^{-1}\right)$} \\
\hline & & & Past & Present & \multicolumn{3}{|c|}{ Future 2021-2050 } \\
\hline & & & 1961-1990 & 1991-2014 & REGCM3 & ALADIN & PROMES \\
\hline & & & $1.6(1.809)$ & $1.176(1.385)$ & $1.46(1.669)$ & $1.41(1.619)$ & $1.35(1.559)$ \\
\hline \multicolumn{3}{|c|}{$C W D\left(\mathrm{~m}^{3} \mathrm{~s}^{-1}\right)$} & \multicolumn{5}{|c|}{$C W E I_{1}=C W D / C W R_{1}\left(C W E I_{2}=C W D / C W R_{2}\right)$} \\
\hline \multicolumn{2}{|c|}{$1991-2014$} & 1.13 & $0.71(0.63)$ & $0.96(0.82)$ & $0.78(0.68)$ & $0.80(0.70)$ & $0.84(0.73)$ \\
\hline Future & $5 \%$ & 1.19 & $0.74(0.66)$ & $1.01(0.86)$ & $0.82(0.71)$ & $0.84(0.74)$ & $0.88(0.76)$ \\
\hline Future & $10 \%$ & 1.25 & $0.78(0.69)$ & $1.06(0.90)$ & $0.85(0.75)$ & $0.88(0.77)$ & $0.92(0.80)$ \\
\hline Future & $15 \%$ & 1.30 & $0.82(0.72)$ & $1.11(0.94)$ & $0.89(0.78)$ & $0.92(0.81)$ & $0.97(0.84)$ \\
\hline Future & $20 \%$ & 1.36 & $0.85(0.75)$ & $1.16(0.98)$ & $0.93(0.82)$ & $0.97(0.84)$ & $1.01(0.87)$ \\
\hline Future & $25 \%$ & 1.42 & $0.89(0.78)$ & $1.21(1.02)$ & $0.97(0.85)$ & $1.01(0.88)$ & $1.05(0.91)$ \\
\hline
\end{tabular}

Average Water Demand (WD) was calculated as the mean annual abstracted flow from the Sv. Ivan, Gradole and Bulaž springs and the Butoniga reservoir in the period of 1991-2014 (with future increases of 5-25\%). Average Water Resources were calculated as the mean annual total flow at the Sv. Ivan, Gradole and Bulaž springs $\left(W R_{1}\right)$, and as the sum of $W R_{1}$ and the mean annual abstracted flow from Butoniga reservoir $\left(W R_{2}\right)$, in the past (1961-1990), present (1991-2014), and future (2021-2050), as predicted by three climate models: REGCM3, ALADIN and PROMES. Characteristic Water Demand (CWD) was computed from the mean August abstracted flow from the Sv. Ivan, Gradole and Bulaž springs as well as the Butoniga reservoir; whereas, Characteristic Water Resources were computed as the minimum mean monthly flow observed at all three springs $\left(C W R_{1}\right)$, and as the sum of $C W R_{1}$ and the mean August abstracted flow from the Butoniga reservoir $\left(C W R_{2}\right)$ for the past, present and future scenarios. When evaluating WEI using the CC-WaterS [33] thresholds, the
WEI values are similar and suggest a very low risk even if the future water demand increases by $25 \%$.

When the original [39] boundary values are considered, all the $W E I$ values indicate moderate water stress. For past water resources, $C W E I_{1}$ indicates a strong risk for all water demand scenarios. When present water resources are considered, $C W E I_{1}$ indicates a strong current risk and an overexploitation of the karst springs for all future demands.

For future water resources, all climate models predict higher $C W E I_{1}$ values than the past ones, suggesting a strong risk for most future water demand scenarios and overexploitation for increases in water demand over $20 \%$ or $25 \%$, depending on the climate model. The results for present water resources that indicate even stronger risks than any future scenario are somewhat misleading, because the present scenario includes an extremely dry event that occurred in August 2012. Future modelled scenarios, clearly, do not anticipate an occurrence of such a strong drought in the period 2021-2050. 
To separately evaluate this extremely dry event from 2012, when a first-degree water restriction was declared in the Istria County, and the karst springs were exploited to their maximum capacity, the $W E I^{2012}$ for the calendar and hydrological year and the $C W E I^{2012}$ for August were additionally evaluated.

Water Demand $\left(W D^{2012}\right)$ was calculated as the mean 2012 abstracted flow from the Sv. Ivan, Gradole and Bulaž springs and the Butoniga reservoir, whereas the water resources were calculated as the mean 2012 total flow at the three springs $\left(W R_{1}{ }^{2012}\right)$, and the sum of the $W R_{1}{ }^{2012}$ and the 2012 abstracted flow from the Butoniga reservoir
$\left(W R_{2}{ }^{2012}\right)$. Characteristic Water Demand $\left(C W D^{2012}\right)$ was calculated as the mean August 2012 abstracted flow from the three springs and the Butoniga reservoir, whereas the Characteristic Water Resources $\left(C W R^{2012}\right)$ were calculated as the mean August 2012 total flow at the three springs $\left(W R_{1}{ }^{2012}\right)$ or the sum of $W R_{1}{ }^{2012}$ and the abstracted flow from the Butoniga reservoir $\left(W R_{2}{ }^{2012}\right)$.

From the results presented in Tab. 3, the hydrological year (possible difficulties) was much more critical than the calendar year (low risk).

Furthermore, $C W E I_{1}{ }^{2012}>1.0$ for August indicates overexploitation and an unsustainable situation.

Table $3 W E I$ for the extremely dry year of 2012 in Northern Istria

\begin{tabular}{|c|c|c|c|}
\hline Period & $W D^{2012}\left(\mathrm{~m}^{3} \mathrm{~s}^{-1}\right)$ & $W R_{1}^{2012}\left(W R_{2}^{2012}\right)\left(\mathrm{m}^{3} \mathrm{~s}^{-1}\right)$ & $2.20(2.35)$ \\
\hline January 2012 - December 2012 & 0.71 & $W E I_{1}^{2012}\left(W E I_{2}^{2012}\right)$ & $0.32(0.30)$ \\
\hline October 2011 - September 2012 & 0.72 & $1.28(1.45)$ & $0.57(0.50)$ \\
\hline Period & $C W D^{2012}\left(\mathrm{~m}^{3} \mathrm{~s}^{-1}\right)$ & $C W R_{1}^{2012}\left(C W R_{2}^{2012}\right)\left(\mathrm{m}^{3} \mathrm{~s}^{-1}\right)$ & $C W E I_{1}^{2012}\left(C W E I_{2}^{2012}\right)\left(\mathrm{m}^{3} \mathrm{~s}^{-1}\right)$ \\
\hline August 2012 & 1.01 & $0.59(1.01)$ & $1.71(1.00)$ \\
\hline
\end{tabular}

This event is clearly characterized by a much longer return period than any future scenario considered here. Nevertheless, such events are not isolated and could be expected again in the future.

\section{CONCLUSIONS}

This paper shows that the analysed Northern Istria region, i.e., the Sv. Ivan, Gradole, and Bulaž springs in Mirna river catchment, has risks of unwanted consequences of climate change and that until the year 2050, even more extreme changes can be expected.

Different models for forecasting changes in climate indicators result in different scenarios of the impact of such changes on the selected water balance indicators. Even the most conservative REGCM3 climate model projected that the lowest monthly discharge in the analysed springs during the period of 2021-2050 could be approximately $8.6 \%$ lower than the average of the 30 -year period of 2021 2050 and that the extreme minimums could be up to $35.4 \%$ lower with far more extreme variations and a potential for even drier years than the extremely dry 2011-12 season. The projections of the other two models used in this paper, ALADIN and PROMES, suggest even more pronounced differences and significantly lower average and extremely low values of the lowest average monthly discharge. All the trends show a decrease in the analysed discharge and therefore the water resources available for water supply.

The WEI results for Northern Istria for average conditions (the mean annual abstracted flow from the Sv. Ivan, Gradole and Bulaž springs, with and without the Butoniga reservoir), using the CC-WaterS [33] thresholds, indicate that there is a very low risk of not meeting future water demands even if they increase by $25 \%$. Similarly, when the original [39] boundary values are considered, all of the values indicate moderate water stress.

Considering the seasonal variability in Northern Istria, the $C W E I$ for past water availability indicates a strong risk for all water demand scenarios. For the current water resources, $C W E I$ indicates a strong current risk; however, any future increases in water demand would result in overexploitation of the karst springs if the Butoniga reservoir is not included. The predicted CWEIs for future water resources are also higher than the past ones, suggesting a strong risk for most future water demand scenarios and overexploitation for increases in water demand greater than $20 \%$.

The extreme dry event that occurred in the summer of 2012 was also examined; the $W E I$ for 2012 and the CWEI for August 2012 were also calculated. The results clearly show that the hydrological year (possible difficulties) was much more critical than the calendar year (low risk). Furthermore, the CWEI for August indicates overexploitation and an unsustainable situation that resulted in a first-degree water restriction that was declared in the Istria County in 2012 when the karst springs were exploited to their maximum capacity. This event was more extreme than any estimated future scenario. Nevertheless, such events are not isolated and could be expected again in the future. It can also be concluded that using water from the Butoniga reservoir in addition to the water from Sv. Ivan, Gradole and Bulaž springs to meet the water demand during critical periods lowers the CWEI by as much as $19 \%$.

Sustainable water resource management requires optimization of the use and also the reduction of excessive exploitation of available water resources. Therefore, to ensure the required water supply quantities and the functionality of the water supply system in Istria in the given climate scenarios and their hydrological consequences, it is essential to develop adequate scenarios of management and structural responses for the spatial and temporal allocation of available resources in cases that are far more unfavourable than the current scenario.

The methodology presented in this paper can be applied to other water resources and locations where the seasonal character in water resources availability and water demand is present. It can be used for longer periods estimation (e.g. until 2100) which gives the possibility to decision makers to better prepare adequate management and structural responses.

\section{Acknowledgements}

This research was supported by the EU IPA Adriatic Cross-Border Cooperation Programme 2007-2013, under project $1^{\circ} \mathrm{STR} . / 0004$, DRINKADRIA: Networking for Drinking Water Supply in the Adriatic Region; and the 
University of Rijeka, under project 13.05.1.3.08 Development of new methodologies in water and soil management in karstic, sensitive and protected areas.

\section{REFERENCES}

[1] Alcamo, J., \& Henrichs, T. (2002). Critical regions: A model-based estimation of world water resources sensitive to global changes. Aquatic Science, 64(4), 352-362. https://doi.org/10.1007/PL00012591

[2] Xoplaki, E., Gonzalez-Rouco, J. F., Luterbacher, J., \& Wanner, H. (2004). Wet season Mediterranean precipitation variability: influence of large-scale dynamics and trends. Climate Dynamics, 23(1), 63-78. https://doi.org/10.1007/s00382-004-0422-0

[3] Milano, M., Ruelland, D., Fernandez, S., Dezetter, A., Fabre, J., \& Servat, E. (2012). Facing climatic and anthropogenic changes in the Mediterranean basin: What will be the medium-term impact on water stress? Comptes Rendus Geoscience, 344(9), 432-440. https://doi.org/10.1016/j.crte.2012.07.006

[4] Collet, L., Ruelland, D., Estupina, V. B., Dezetter, A., \& Servat, E. (2015). Water supply sustainability and adaptation strategies under anthropogenic and climatic changes of a meso-scale Mediterranean catchment. Science of the Total Environment, 536, 589-602. https://doi.org/10.1016/j.scitotenv.2015.07.093

[5] Šraj, M., Brilly, M., \& Mikoš, M. (2008). Rainfall interception by two deciduous Mediterranean forests of contrasting stature in Slovenia. Agricultural and Forest Meteorology, 148(1), 121-134. https://doi.org/10.1016/j.agrformet.2007.09.007

[6] Gutiérrez, A. P. A., Engle, N. L., De Nys, E., Molejón, C., \& Martins, E. S. (2014). Drought preparedness in Brazil. Weather Climate Extremes, 3, 95-106. https://doi.org/10.1016/j.wace.2013.12.001

[7] Sisto, N. P., Ramırez, A. I., Aguilar-Barajas, I., \& MaganaRueda, V. (2016). Climate threats, water supply vulnerability and the risk of a water crisis in the Monterrey Metropolitan Area (Northeastern Mexico). Physics and Chemistry of the Earth, 91, 2-9. https://doi.org/10.1016/j.pce.2015.08.015

[8] Xu, Z. X., Chen, Y. N., \& Li, J. Y. (2004). Impact of climate change on water resources in the Tarim River basin. Water Resources Management, 18(5), 439-458. https://doi.org/10.1023/B:WARM.0000049142.95583.98

[9] Huang, S., Chang, J., Huang, Q., Chen, Y., \& Leng, G. (2016). Quantifying the relative contribution of climate and human impacts on runoff change based on the Budyko hypothesis and SVM model. Water Resources Management, 30(7), 2377-2390. https://doi.org/10.1007/s11269-016-1286-x

[10] Xu, C. (2000). Modelling the effects of climate change on water resources in central Sweden. Water Resources Management, 14(3), 177-189. https://doi.org/10.1023/A:1026502114663

[11] Fiseha, B. M., Setegn, S. G., Melesse, A. M., Volpi, E., \& Fiori, A. (2014). Impact of climate change on the hydrology of upper Tiber River Basin using bias corrected regional climate model. Water Resources Management, 28(5), 13271343. https://doi.org/10.1007/s11269-014-0546-x

[12] Hanel, M., Vizina, A., Maca, P., \& Pavlasek, J. (2012). A multi-model assessment of climate change impact on hydrological regime in the Czech Republic. Journal of Hydrology and Hydromechanics, 60(3), 152-161. https://doi.org/10.2478/v10098-012-0013-4

[13] Verzano, K., Bärlund, I., Flörke, M., Lehner, B., Kynast, E., Voß, F., \& Alcamo, J. (2012). Modeling variable river flow velocity on continental scale: Current situation and climate change impacts in Europe. Journal of Hydrology, 424, 238251. https://doi.org/10.1016/j.jhydrol.2012.01.005
[14] Lespinas, F., Ludwig, W., \& Heussner, S. (2014). Hydrological and climatic uncertainties associated with modeling the impact of climate change on water resources of small Mediterranean coastal rivers. Journal of Hydrology, 511, 403-422. https://doi.org/10.1016/j.jhydrol.2014.01.033

[15] Mizyed, N. (2009). Impacts of climate change on water resources availability and agricultural water demand in the West Bank. Water Resources Management, 23(10), 20152029. https://doi.org/10.1007/s11269-008-9367-0

[16] Martinez, S., Kralisch, S., Escolero, O., \& Perevochtchikova, M. (2015). Vulnerability of Mexico City's water supply sources in the context of climate change. Journal of Water and Climate Change, 6(3), 518-533. https://doi.org/10.2166/wcc.2015.083

[17] Baltas, E. A. (2013). Measures against climate change and its impact on water resources in Greece.International Journal of Water Resources Development, 29(2), 237-249. https://doi.org/10.1080/07900627.2012.721710

[18] Karleuša, B., Rubinić, J., Radman, I., Volf, G., \& Krvavica, N. (2016). Cross-Border Water Resources Management in Present Conditions and for Future Scenarios. Proceedings of International Symposium: Cross-border drinking water management, Rijeka: Faculty of Civil Engineering University of Rijeka, 59-90.

[19] Kanakoudis, V., Tsitsifli, S., Papadopoulou, A., ČenčurCurk, B., \& Karleuša, B. (2017). Water resources vulnerability assessment in the Adriatic Sea region: the case of Corfu Island. Environmental Science and Pollution Research, 24(25), 20173-20186. https://doi.org/10.1007/s11356-017-9732-8

[20] (2009, March 12). Water resources across Europe confronting water scarcity and drought (Report No. 2). Copenhagen: European Environment Agency. Retrieved from https://www.eea.europa.eu/publications/waterresources-across-europe

[21] Bonacci, O. (2001). Monthly and annual effective infiltration coefficients in Dinaric karst: example of the Gradolekarst spring catchment. Hydrological Sciences Journal, 46(2), 287-299. https://doi.org/10.1080/02626660109492822

[22] Rubinić, J., Kogovšek, J., Diković, S., Petrič, M., Hrvojić, E., Knez, M., \& Slabe, T. (2006). Vode gornjeg i srednjeg toka rijeke Mirne (Waters of upper and middle course of Mirna river). Hrvatske vode, 14(54), 1-14.

[23] Rubinić, J., Cindrić Kalin, K., Nežić, M., Radišić, M., \& Ružić, I. (2015). Ekstremena suša na izvorištima vodoopskrbe u slivu Mirne tijekom 2012. godine (Extreme drought at water supply sources in the Mirna river basin during 2012). Proceedings of $6^{\text {th }}$ Croatian water conference, Opatija: Hrvatske vode, 171-180.

[24] Rubinić, J., \& Katalinić, A. (2014). Water regime of Vrana Lake in Dalmatia (Croatia): changes, risks and problems. Hydrological Sciences Journal, 59(10), 1908-1924. https://doi.org/10.1080/02626667.2014.946417

[25] Langbein, W. B. (1962). The water supply of arid valleys in intermountain regions in relation to climate. IAHS Bulletin, 7(1), 34-39.

[26] Turc, L. (1954). Le biland'eau des sols: Relations entre les precipitations, l'evaporation et l'ecoulement. Annales Agronomiques, 5, 491-595; 6, 5-131.

[27] Bonacci, O. (1987). Karst hydrology. Berlin: Springer Verlag.

[28] Horvat, B. \& Rubinić, J. (2006). Annual runoff estimation an example of karstic aquifers in the transboundary region of Croatia and Slovenia. Hydrological Sciences Journal, 51(2), 314-324. https://doi.org/10.1623/hysj.51.2.314

[29] Žugaj, R. (2015). Hidrologija (Hydrology). Zagreb: Faculty of Mining, Geology and Petroleum Engineering University of Zagreb.

[30] Pal, J. et al. (2007). Regional Climate Modeling for the Developing World: The ICTP RegCM3 and RegCNEt. 
Bulletin of the American Meteorological Society, 88(9), 1395-1409. https://doi.org/10.1175/BAMS-88-9-1395

[31] Bubnova, R., Hello, G., Benard, P., \& Geleyn, J. (1995). Integration of the Fully Elastic Equations Cast in the Hydrostatic Pressure Terrain - Following Coordinate in the Framework of the ARPEGE/ Aladin NWP System. Monthly Weather Review, 123, 515-35. https://doi.org/10.1175/15200493(1995)123<0515:IOTFEE>2.0.CO;2

[32] Castro, M., Fernández C., \& Gaertner M. A. (1993). Description of a meso-scale atmospheric numerical model. In J. I. Díaz\& J. L. Lions (Eds), Mathematic, climate and environment, Masson,

[33] CC-WaterS (2012, February). WP4 Availability of Water Resources (Final Report). Climate Change and Impacts on Water Supply. Retrieved from http://www.ccwaters.eu/ downloads/CC-WaterS_Final\%20report_WP4_3.pdf

[34] Wilcoxon, F. (1945). Individual Comparisons by Ranking Methods. Biometrics Bulletin, 1(6), 80-83. https://doi.org/10.2307/3001968

[35] Sen, P. K. (1968). Estimates of the regression coefficient based on Kendall's tau. Journal of American Statistical Association, 63, 1379-1389. https://doi.org/10.1080/01621459.1968.10480934

[36] Theil, H. (1950). A rank-invariant method of linear and polynomial regression analysis, I, II, III. Nederl. Akad. Wetensch. Proc.53, 386-392, 512-525, 1397-1412. https://doi.org/10.1007/978-94-011-2546-8_20

[37] Mann, H. B. (1945). Non-parametric tests against trend. Econometrica, 13, 163-171. https://doi.org/10.2307/1907187

[38] Kendall, M. G. (1975). Rank Correlation Methods, $4^{\text {th }}$ edition. London: Charles Griffin.

[39] Raskin, P., Gleick, P. H., Kirshen, P., Pontius, R. G., \& Strzepek, K. (1997). Comprehensive assessment of the freshwater resources of the world. Document prepared for UN Commission for Sustainable Development 5th Session 1997. Technical report, Stockholm Environmental Institute. Retrieved from http://www.un.org/esa/documents/ecosoc/ cn17/1997/ecn171997-9.htm

[40] Alcamo, J., Henrich, T., \& Rösch, T. (2000). World water in 2025 - global modelling and scenario analysis for the World Commission on Water for the $21^{\text {st }}$ Century (Report No. 2.). Kassel: Centre for Environmental System Research, University of Kassel. Retrieved from http://hdl.handle.net/ 20.500.11822/19071

[41] Smakhtin, V., Revenga, C., \&Döll, P. (2004). Taking into account environmental water requirements in global-scale water resources assessments, Colombo, Sri Lanka: International Water Management Institute. Retrieved from http://hdl.handle.net/10568/39741

[42] Branković, Č., Güttler, I., \& Gajić-Čapka, M. (2013). Evaluating climate change at the Croatian Adriatic from observations and regional climate models' simulations. Climate Dynamics, 41, 2353-2373. https://doi.org/10.1007/s00382-012-1646-z

[43] (2012). Census of Population, Households and Dwellings 2011. Zagreb: Croatian Bureau of Statistics. Retrieved from https://www.dzs.hr/eng/censuses/census2011/results/census tabshtm.htm

[44] (2007). Vodoopskrbni plan Istarske županije (Water Supply Plan of Istrian region). Rijeka, Zagreb: Civil Engineering Institute of Croatia. Retrieved from http://www.voda.hr/system/tdf/dokumenti/istarska.pdf?file= $1 \&$ type $=$ node $\& \mathrm{id}=2075 \&$ force $=1$

\section{Contact information:}

Barbara KARLEUŠA, Professor, PhD

(Corresponding author)

Faculty of Civil Engineering, University of Rijeka

Radmile Matejčić 3, 51000 Rijeka, Croatia

barbara.karleusa@uniri.hr

Josip RUBINIĆ, Assistant professor, PhD

Faculty of Civil Engineering, University of Rijeka Radmile Matejčić 3, 51000 Rijeka, Croatia jrubinic@uniri.hr

Maja RADIŠIĆ, PhD student

Faculty of Civil Engineering, University of Rijeka Radmile Matejčić 3, 51000 Rijeka, Croatia maja.radisic@uniri.hr

Nino KRVAVICA, Postdoctoral researcher, PhD Faculty of Civil Engineering, University of Rijeka Radmile Matejčić 3, 51000 Rijeka, Croatia nino.krvavica@uniri.hr 